\title{
EMPLOYMENT OF FOREIGNERS IN ENTERPRISES
}

\author{
DOI: 10.17261/Pressacademia.2018.992 \\ JBEF- V.7-ISS.4-2018(1)-p.325-331
}

\section{Mahmut Kabakci ${ }^{1}$, Arzu Hacioglu²}

${ }^{1}$ Istanbul Technical University, Management Engineering, Macka Campus, Istanbul, Turkey. mkabakci@itu.edu.tr, ORCID: 0000-0003-1261-8310

${ }^{2}$ Istanbul Technical University, Management Engineering, Macka Campus, Istanbul, Turkey. haciogluar@itu.edu.tr, ORCID: 0000-0003-1652-4012

\begin{abstract}
Purpose- Purpose of this study is to present the legal requirements of hiring foreign employees in Turkey.

Methodology- The topic will be examined within the frame of new legislation on the work permits of foreigners.

Findings- In 2016, Turkish lawmaker enacted new legislation numbered 6735. The Law numbered 6735 introduces new concepts such as preliminary permission, turquoise card etc. Main motive behind this change is to bring qualified labour force and labour capital into Turkey on one hand; to facilitate high skilled foreigners' work permit applications on the other hand.

Conclusion- Law numbered 6735 is a product of a policy change regarding the entrance of foreign labour force into Turkish market.
\end{abstract}

Keywords: Foreigner, work permit, exemption of work permit, turquoise card, preliminary permission.

JEL Codes: K31, K37, K38

\section{INTRODUCTION}

The increase of foreign labour force into Turkish labour market is a well-known fact. Statistics published by the Ministry of Family, Labour and Social Services support this phenomenon. According to these statistics, number of work permits given in 2011 was 17.446 and increased to 32.279 in 2012. Although there was no such leap between the consecutive years' statistics, the number has continued to increase. In the latest statistics of 2016, this number has reached to 73.560 (see. https://www.csgb.gov.tr/media/7315/yabancilarin\%C3\%A7ali\%C5\%9Fma\%C4\%B0z\%C4\%B0nler\%C4\%B0-2016.pdf).

One of the reasons behind this increase is the rise of the foreign capital enterprises operating in Turkey. Such companies tend to employ foreigners especially in the field of management or other specialization-required fields. However, this kind of employment may contain legal risks, as the foreign employment requires certain legal procedures under Turkish law.

Recently, Turkish lawmaker enacted legislation in 2016 to bring qualified foreign labour into the country and to promote foreign capital to operate in Turkey by way of providing legal convenience regarding foreign employment with the Law numbered 6735 on the International Labour Force (O.J. 13.08.2016, 29800). The law in question abolished the Law numbered 4817 on the Work Permits of Foreigners (O.J. 06.03.2003, 25040) with the purpose of determining policy on a new international labour force. With this study, legal regime of the foreign employment in enterprises will be assessed under the Law numbered 6735.

\section{THE TERM OF “FOREIGNER"}

There is no doubt regarding foreigners to have right to work, as the art.49 of Turkish Constitution ensures the right to work as every persons' right and duty. Nevertheless, art.16 of the Constitution creates a margin for lawmaker to regulate the foreigners' fundamental rights and freedoms outside the general restriction regime of the fundamental rights and freedoms: The fundamental rights and freedoms of foreigners may only be restricted by law in accordance with international law. As in all over 
the world, foreigners' right to work is restricted by law in our country, too. First, employment of foreigners is subject to work permit. Moreover, certain professions and occupations are allotted only to Turkish citizens.

The idea behind the restriction of foreigners' right to work is to protect citizens' right primarily (Lordoğlu, 2007: 21). Restriction on the employment of the foreigners is a common measure taken by almost every state to prevent unemployment of its citizens (Marhold, Franz/Friedrich, Michael, 2012: 5-26; Koch, 2015: 197 ff; Geiser, Thomas/ Müller, Roland, 2012: 99). In addition, the concern for the decrease in wages constitutes a basis for the restriction (Lordoğlu, 2007: 21).

As it is stated above, who are the "foreigners" whose right to work is restricted under Turkish law? In Turkish Law, foreignness is a qualification that can be considered for legal persons as well as real persons (Çelikel/ Öztekin Gelgel, 2017: 16). However, since this study is exclusive to foreign employment, the concept will be discussed here only in terms of real persons.

Foreignness could be defined in the light of citizenship (Çelikel/ Öztekin Gelgel, 2017: 16). Persons who are not the citizen of a country they reside are called "foreigner" (Ekşi, 2016: 40). In line with this, persons who do not possess Turkish citizenship are considered foreigners. This definition is literally accepted in the Law on International Labour Force (Law no. 6735, art. 3/ I/ I). Stateless persons (heimatlos), refuges, asylum seekers etc. are also regarded as foreigners as well as persons who have foreign citizenship (Ekşi, 2016: 41; Çelikel/ Öztekin Gelgel, 2017: 16).

Having said that, there is a group of foreigners treated same or similarly to Turkish citizens. One of them is the foreigners and their descendants that are in the scope of art.28 of Law numbered 5901 (0.J. 12.06.2009, 27256). Those are the foreigners who had been Turkish citizens by birth but lost it by obtaining a renunciation permit. They are known as blue cardholder as this card is issued on their demand. Foreigners belong to this group are regarded privileged foreigners (For definition see. Çelikel/ Öztekin Gelgel, s. 189). Another group that could be defined as privileged is foreigners having Turkish descent. Similarly, citizens of Turkish Republic of Northern Cyprus and EU member countries are qualified as privileged foreigners. The privileges given to these foreigners will be explained in the relevant sections.

\section{GENERAL REGULATION REGARDING EMPLOYMENT OF FOREIGNERS AND ITS SCOPE}

Work permits, and exemption of work permits to be issued to foreigners are generally regulated under the Law on International Labour Force numbered 6735. However, either bilateral or multilateral treaties which Turkey is a party to or other acts may contain provisions regarding prohibition or exemption of foreign employment. Actually, art. 2 of the Law no. 6735 refers such provisions, hence reveals the patch worked nature of the relevant regulations.

Article 2 of the Law no. 6735 covers the foreigners who apply to work in Turkey either dependently or independently. However, the scope of the regulation is not limited to this. Law no. 6735 also covers foreigners wishing to undertake vocational training or internship. The Law also covers cross-border service providers who plan to stay in Turkey temporarily to render service. In addition to these, employers who employ foreigners are within the scope of Law, concerning their obligations.

Foreigners who had been Turkish citizens by birth but lost it by obtaining a renunciation permit and their descendants are out of scope of the Law no. 6735. In fact, relevant provision of Law no. 5901 states that these foreigners are to enjoy rights granted to Turkish citizens- with certain exceptions. Exceptions counted in art.28 of Law no. 5901 do not contain right to work. Yet, to prevent hesitation, Law no. 6735 reserved the right of foreigners who had been Turkish citizens by birth but lost it by obtaining a renunciation permit by a clear provision (Law no. 6735 art.6/ IV, also see the motive of the legislation draft http://www2.tbmm.gov.tr/d26/1/1-0727.pdf ). It is necessary and sufficient for those to present the blue cards given to them when enjoying their rights.

Foreigners who had been Turkish citizens by birth but lost it by obtaining a renunciation permit cannot be employed as civil servant but may work as worker or contracted personnel in public institutions under public law regime (Law no. 5901 art.28/ III).

\section{PRINCIPLE: WORK UNDER WORK PERMIT OR EXEMPTION OF WORK PERMIT}

\subsection{In General}

Foreigners within the scope of Law numbered 6735 are prohibited to work or to be employed in Turkey without work permit (Law no. 6735 art.6/II). This prohibition has been imposed for those who work independently on their own behalf as well as the dependent employees working with the employment contract. Moreover, the law requires even foreigners who are exempted of obtaining work permit to follow a procedure and document the exemption (Law no. 6735, art.13). In our country, where the phenomenon of undeclared work is quite common, we believe that this obligation has been introduced as a means of combating undeclared work in foreign employment. 
As stated above, foreigners within the scope of art.28 of Law no. 5901 have right to work without work permit or exemption of work permit as they fall outside the scope of the Law no. 6735. Also, in the case of specific provisions in international treaties, which Turkey is party to provisions in the treaties prevail Law no. 6735.

Refuges and persons who are under subsidiary protection status defined in the Law numbered 6458 on Foreigners and International Protection (O.J. 11.04.2013, 28615), may work dependently or independently in Turkey from the moment they acquired the said status. The identity card issued to these persons is deemed as work permit (Law no. 6458 art.89/ IV/ b).

\subsection{Work Permit}

\subsubsection{Types of Work Permits}

Law no. 6735 counts five different work permits: work permit for a definite period, permanent work permit, freelance work permit, exceptional work permit and the turquoise card (for the argument that Law no. 6735 lists 4 kinds of work permit see. Ergin, 2016: 113). If we put aside the freelance work permit, the main principle is foreigners to apply for a definite-period work permit. On the first application, work permits are given for a maximum of one year, as long as they do not exceed the duration of the employment contracts. The work permits are granted on the condition that the foreigner to work in a particular workplace of an employer or to work in a specific job in various workplaces of an employer in the same sector (Law no. 6735, art.10/ I). It is possible to exceed the duration of work permit. In the first application for extension maximum two years of permit is granted, for the following extension applications maximum period for work permit is three years. Nevertheless, when the applicant wishes to work for a different employer, application for extension is evaluated as it is the first application for work in Turkey, therefore maximum one year of permit can be granted (Law no. 6735, art.10/ II).

Permanent work permit could be granted to the foreigners who are long-term residence permit holders or who have at least eight years of legal work permit (Law no. 6735, art.10/ III). Foreigners who obtain a permanent work permit benefit from the rights granted to Turkish citizens, unless otherwise is provided. However, those persons cannot be appointed for civil service duty (Law no. 6735, art.10/IV).

The implementation of turquoise card is introduced for the first time with Law no. 6735 with the intent of gaining high skilled labour and to increase competitiveness of Turkey at international level. This permit is a facilitated work permit (see the motive of the legislation draft http://www2.tbmm.gov.tr/d26/1/1-0727.pdf) and aims to provide permanent work permit to foreigners with certain qualifications (Law no. 6735, art.11/ IV). Unlike the permanent work permit, a 3-year transition period is required. Applicants who are assessed as qualified workforce due to their educational level, wage, professional experience, contribution to science and technology etc. or assessed as qualified investor due to their contribution to science and technology, their level of investment or export value, volume of employment they provide or scientists and researcher who have internationally recognized studies in the academic area, and those distinguished in science, industry and technology, areas of which deemed strategic from the point of our country or internationally reputed for their successes in cultural, artistic or sports activities or contributing the recognition or publicity of Turkey or its culture internationally, acting in favour of the matters concerning Turkey's national interests are regarded as qualified foreigner (Law no. 6735, art.11/ V).

Exceptional work permit is permit which enables to make an exception for foreigners due to their qualifications in terms of procedure, evaluation or duration of the work permits (Çelikel/ Öztekin Gelgel, 2017: 198). Foreigners who could be granted exceptional work permit are counted in art.16 of Law no. 6735. According to this, foreigners who are regarded as qualified labour or investor; foreigners having Turkish descent; foreigners who are citizens of Turkish Republic of Northern Cyprus and EU member countries; foreigners who are married to a Turkish citizen and live in a marriage union with their spouse in Turkey; foreigners who are applicant of international protection; conditional refuge; provided provisional international protection or heimatlos pursuant to Law no. 6458 could benefit from these exceptions.

\subsubsection{Preliminary Permission}

Law no. 6735 which is adopted to bring high skilled labour force in our country, has imposed an obligation of obtaining "preliminary permission" for the foreigners who are to work in certain professions require occupational competence and expertise.

Professions and the sectors require preliminary permission are counted in art.8 of Law no. 6735. According to this provision, for health services Ministry of Health, for education services Ministry of National Education are authorized for granting preliminary permission. The Ministry of Family, Labour and Social Services determine professions that require preliminary permits on the positive opinion of the above-mentioned ministries. 
Foreign faculty members who are to work in accordance with art.34 of Higher Education Law No. 2547 (0.J. 06.11.1981, 17506) are also subject to preliminary permission. Accordingly, the Council of Higher Education is authorized for the permit (Law no. 6735, art.8/IV).

There is also preliminary permission requirement for foreigners who are working as research and development personnel in companies with the Certificate of R\&D Center under Law no. 5746 (O.J. 12.03.2008, 26814). It is stated in art.8 of Law no. 6735 that such persons' application for work permit are evaluated on the positive opinion of the Ministry of Science, Industry and Technology.

It is crucial to state that preliminary permission is not a one-time only requirement. Application for extension of work permits are subject to preliminary permission of relevant ministry or Council of Higher Education too (Law no. 6735, et.7/ V).

\subsubsection{Procedure and Evaluation of the Application}

Foreigners are obliged to get a work permit before starting to work in Turkey (Çelikel/ Öztekin Gelgel, 2017: 188). Art.7 of Law no. 6735 regulates the procedure of work permit applications. The application can be made by the foreigner in person or by the authorized intermediary institution (Law no .6735 , art.7/ II).

Applications are made to the Ministry of Family, Labour and Social Services (Referred to as "Ministry" hereafter), when foreigner applies from Turkey. Applications from outside Turkey could be made to Turkish Embassies or Consulate Generals in countries where the applicant is a citizen of or legally resides. Such applications are transmitted to the Ministry by the embassies or consulate generals (Law no. 6735, art.7/I).

Persons who are employed in foreign countries' diplomatic or consular missions in Turkey and subject to work permit applies to the Ministry of Foreign Affairs (Law no. 6735, art.14). In a similar manner, foreigners who work within the scope of Free Trade Areas Law no. 3218 (O. J. 15.06.1985, 18785) apply to the Ministry of Economy for work permit; those whose applications are approved by the Ministry of Economy are forwarded to the Ministry.

The Ministry assesses applications for work permit pursuant to international labour force policy. Law no. 6735 has also introduced a point scoring system based on the criteria in line with the Advisory Council of International Labour Force Policy. By this means, objective basis for the work permit application can be provided (Law no. 6735, art.7/ IV, VI).

In case of lack of information or documents, the evaluation of the application is postponed until these deficiencies are completed. The period of postponement takes maximum of 30 days in principle. At the end of the postponement period, applications whose deficiencies are not completed are rejected (Law no. 6735, art.7/ VII). The application is evaluated within 30 days (Law no. 6735, art.8).

The grounds for the refusal of the work permit application are listed in art. 9 of the Law no. 6735. According to this, applications made with false or misleading information and documents, applications for the jobs and professions allotted only to Turkish citizens, applications that are not submitted within the legal period or whose shortcomings are not completed will be rejected. Apart from this, applications which are not in compliance with the international labour force policy, applications of the foreigners who do not possess the necessary qualification or expertise, applications of foreigners who cannot meet the evaluation criteria determined by the Ministry, applications of foreigners who deemed prejudicial regarding public order, public health etc. are rejected. The grounds for the rejection listed in the second group are separated from the ones mentioned in the first group in terms of the discretionary power of the administration.

\subsection{Exemption of Work Permit}

Foreigners exempted from work permit can work in Turkey provided they obtain exemption of work permit. However, which foreigners are exempted from work permit has not been clarified in art.13 of the Law 6735. In art.13, only member of Board of Directors in a joint stock company who does not reside in Turkey and partners of other companies who are not director and cross border service providers whose operations do not exceed more than 90 days in a period of 180 days are exempted from work permit. Foreigners exempted from work permit and the sectors are to be regulated in by law (Law no. 6735, art.25/ I/ b). Nevertheless, said by law has not been issued yet. On that matter, Regulation on the Implementation of Foreigners' Work Permits (O. J. 29.08.2003, 25214) based on abolished Law numbered 4817 has to be applied. Because, the provisional article 1 of Law no. 6735 clearly stipulates that the current regulations shall be in force until the by laws regarding the implementation of Law no. 6735 are issued, unless they are inconsistent to Law no. 6735. 
Application for exemption of work permit can be made by an authorized intermediary institution such as work permit applications (Law no. 6735, art. 13/ III). Applications within the country are made directly to the Ministry. Applications from abroad are made to Turkish Embassies or Consulate Generals in countries where the applicant is a citizen of or legally resides. These applications are transmitted to the Ministry by the embassies or consulate generals (Law no. 6735, art.13/ II).

Application for exemption of work permits are assessed according to international labour force policy as well.

\subsection{Foreigners Subject to Special Conditions}

Some foreigners are subject to different principals in terms of work permits and exemption of work permit due to their purpose of entry to country, field of work. These persons will be discussed below.

As stated above, refuges and persons who are under subsidiary protection within the scope of Law no. 6458 can work in Turkey without work permit or exemption of work permit. For that, they must obtain refugee or secondary protection status (Law no. 6458, art.89/ IV/ b). Nonetheless, foreigners who are applicant of international protection; conditional refuge; provided provisional international protection may work when they obtain work permit or exemption of work (Law no. 6735, art.17/ I). On the other hand, applications of said persons are specifically regulated in article 17 of Law no. 6735 .

Foreigners whose applications for international protection have not been finalized yet, conditional refuges, foreigners provided provisional international protection cannot apply for work permit/ exemption of work before six months after the date of the application of the first international protection application or the date on which the temporary protection identification is issued (Law no. 6735, art.17/I). Also, applications of these foreigners require positive opinion of the Ministry of Interior (Law no. 6735 , art. 17/ II).

Similarly, foreigners who are studying for bachelor, master or doctoral degree in Turkey can work in Turkey by obtaining work permit (Law no. 6458, art.41/I). However, the work permits of foreign students have been regulated in a different way in the Law No. 6735.

Art.19 of Law allows foreigners who seek 2-year or bachelor's degree to apply for work permit after completing of first year of their education. Such students can only work with part-time employment contract pursuant to the Labour Code numbered 4857.

It is pointed in the motive of the art.19, the provision aims to ensure that students continue their education and to define the students who continue their education and are successful as eligible for work permit.

It is crucial to note that the limitations regarding the application of work permit and the type of employment contract are not applicable to the graduate students enrolled in formal education programmes (Law No. 6735, art. 19/ II).

Foreign architect and engineer's application are also regulated with special provisions. Law on The Union of Chambers of Turkish Engineers and Architects numbered 6235 (O. J. 04.02.1954, 8625) imposes a general obligation of enrolment in order the architects and engineers to practice. In addition to that, relevant provisions of the Law numbered 6235 requires the opinion of the union of the chambers for issuing work permit to foreign architects and engineers. Law no 6735 has provided a facilitated procedure for the architects and engineers who received their title by completing their education in faculties of architecture or engineering in one of the Turkish higher education institutions or in a higher education institution in abroad which is recognized by the Council of Higher Education. Such persons can only practice engineering and architectural professions by obtaining project-based and temporary work permits.

\section{PROFESSIONS AND OCCUPATIONS PROHIBITED TO FOREIGNERS}

Certain professions and occupations are allotted to Turkish citizens; therefore, foreigners cannot practice these professions even with a work permit. Such professions and occupations are as follows:

-Dentistry and nursing (Law no. 1219, art.30, 63)

-Pharmacy (Law no. 6197, art.2)

-Veterinary (Law no. 6343, art.2)

-Director in charge in private hospital (Law no. 2219, art.9)

-Attorneyship (Law no. 1136, art.3) 
-Notaryship (Law no. 1512, art.7)

-Private security (Law no. 5188, art. 10)

-Customs consultancy (Law no. 4458, art.227, 228)

-Tour guiding (Law no. 6326, art.3)

It should be noted that the abovementioned prohibition is not applicable to foreigners having Turkish descent. Pursuant to article 3 of the Law numbered 2527 (O. J. 29.09.1981, 17473), foreigners having Turkish descent can be employed or work independently for the jobs allotted to Turkish citizens as long as they obtain work permit (although, those foreigners cannot be employed in Turkish Armed Forces).

\section{LEGAL CONSEQUENCES OF FOREIGN EMPLOYMENT CONTRARY TO THE LAW NUMBERED 6735}

The audits to be carried out to ensure the implementation of the Law are carried out by the labour inspectors of the Ministry and the social security inspectors (Law no. 6735, art. 23/ I).

In addition, the audit personnel of the public administrations and the law enforcement officers are obliged to inform the Ministry in case of violation of the obligation stated in the Law no. 6735 (Law no. 6735, art. 23/ II).

Foreigners working without work permit and employers and their representatives who employ foreigners without work permit are charged with administrative fine pursuant to article 23 of Law no. 6735. In addition, foreigners detected to be working without work permit are reported to the Ministry of Interior to be deported.

Employers or representatives of employer must pay for the accommodation expenses and other expenses necessary for foreigners to return their country and health expenses if necessary. In case these expenses are covered from the General Directorate of Migration Management' budget, the Directorate recourse to employers or representatives of employer (Law no. 6735 , art.23/IX).

The effect of violation of the Law no. 6735 on the employment contracts between the foreigner and his/ her employer is not regulated in Law no. 6735. This problem needs to be examined in two phases. Employment contracts made for the jobs allotted only to Turkish citizens are deemed null and void; therefore, they are invalid since the beginning (Ergin, 2007: 1372-1373; Cengiz, 2008: 207; Süzek, 2016: 338).

The fate of the employment contracts concluded without work permit or exemption of work permit is controversial. Some of the scholars argue that the contract should be invalid in this case too (Süzek, 2016: 338- 340; Doğan Yenisey, 2014: 293) however, invalidity of the contract should not have a retroactive effect (Mollamahmutoğlu/ Astarlı/ Baysal, 2014: 502). As opposed to that, some scholars argue that failing to obtain work permit does not affect the validity of the employment contract (Cengiz, 2008: 208; Ergin, 2007: 1387-1388) but provides grounds for termination of it (Akyiğit, 1990: 26).

\section{CONCLUSION}

Law numbered 6735 abolished the Law numbered 4817 on the Work Permits of Foreigners. Although Law numbered 4817 has been into force for just 15 years, Turkish lawmaker has enacted new legislation regarding the work permits of foreigners. Law no. 6735 aims to compete in international labour market by bringing high skilled professionals into country. For that purpose, Turkish legislators have accepted new concepts. With the implementation of turquoise card, applications of certain foreigners who could be considered "qualified" are facilitated. On the other hand, certain field of expertise, such as education and health, have been subjected to preliminary permission.

There is also a significant change concerning the exemption of work permits. From now on, foreigners exempted of work permit must make an application in order to obtain exemption. Otherwise, both the foreigner and his/ her employer would be liable for the violation of Law no. 6735.

Violation of provisions regulated in Law no. 6735 has serious consequences. First, there is administrative fine that would be imposed on the foreigner himself and his employer or the representative of the employer. In addition to that, foreigners are faced deportation in case of employment without work permit. 


\section{REFERENCES}

Akyiğit, E. (1990). Teori ve uygulama bakimindan hizmet akdinin kesin hükümsüzlüğü ve iptal edilebilirliği. İstanbul.

Cengiz, í. (2008). Türk hukukunda yabancilarin iş sözleşmesi ehliyeti. Çalışma ve Toplum, 4: 187- 211.

Çelikel, A., Öztekin Gelgel, G. (2017). Yabancılar hukuku. Yenilenmiş 23. Bası. İstanbul.

Doğan Yenisey, K. (2014). İş Hukukunun emredici yapısı. İstanbul.

Ekşi, N. (2016). Yabancılar ve uluslararasi koruma hukuku. 4. Baskı, İstanbul.

Ergin, H. (2016). Uluslararası işgücü kanunu ile yabancilarin çalişma izinlerine ilişkin getirilen yenilikler. Sicil i̇ş Hukuku Dergisi, $36: 107-118$.

Ergin, H. (2007). Yabancıların çalişma ve ikamet izninin iş sözleşmesine etkisi. Legal isGHD, 16: 1359- 1402.

Geiser, T., Müller, R. (2012). Arbeitsrecht in Der Schweiz, Zweite Auflage. Bern.

Koch, U. (2015). § 27 Beschäftigung ausländischer Arbeitnehmer in der Bundesrepublik Deutschland in Arbeitsrecht Handbuch, 16. neu bearbeitete Auflage, München.

Lordoğlu, K. (2007). Türkiye'deki çalişma hayatinin bir parçasi olarak yabanci çalişanlar. Çalışma ve Toplum, 3: $11-31$.

Mollamahmutoğlu, H., Astarlı, M., Baysal, U. (2014). İş hukuku, gözden geçirilmiş ve genişletilmiş 6. Bası. Ankara.

Süzek, S. (2016). İş hukuku. Yenilenmiş 12. Baskı, İstanbul.

https://www.csgb.gov.tr/media/7315/yabancilarin\%C3\%A7ali\%C5\%9Fma\%C4\%B0z\%C4\%B0nler\%C4\%BO-2016.pdf

http://www2.tbmm.gov.tr/d26/1/1-0727.pdf 